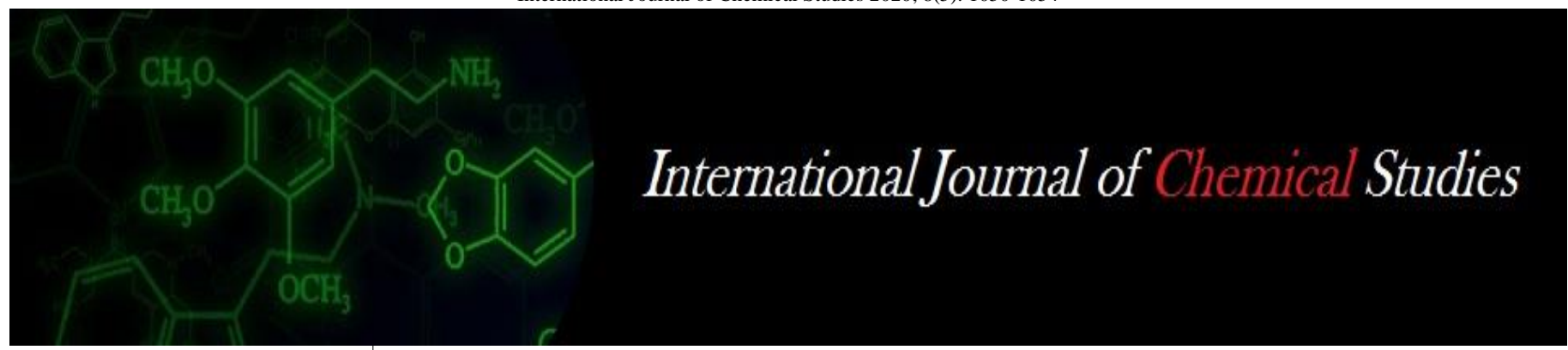

P-ISSN: 2349-8528

E-ISSN: 2321-4902

www.chemijournal.com

IJCS 2020; 8(5): 1050-1054

(C) 2020 IJCS

Received: 15-06-2020

Accepted: 30-07-2020

\section{S Deepthi Gowda}

Department of Plant Pathology,

Kittur Rani Channamma College

of Horticulture, Arabhavi,

Karnataka, India

Amruta S Bhat

Department of Plant Pathology,

Kittur Rani Channamma College

of Horticulture, Arabhavi,

Karnataka, India

Sandhyarani Nishani

Department of Plant Pathology, Kittur Rani Channamma College of Horticulture, Arabhavi,

Karnataka, India

\section{Kantharaju}

Department of Plant Pathology, Kittur Rani Channamma College of Horticulture, Arabhavi,

Karnataka, India

\section{Abdul Kareem}

Department of Plant Pathology, Kittur Rani Channamma College of Horticulture, Arabhavi,

Karnataka, India

\section{HP Hadimani}

Department of Plant Pathology, Kittur Rani Channamma College of Horticulture, Arabhavi,

Karnataka, India

Corresponding Author:

S Deepthi Gowda

Department of Plant Pathology, Kittur Rani Channamma College of Horticulture, Arabhavi,

Karnataka, India

\section{Morphological and cultural variability of Fusarium spp. causing wilt in chilli in Karnataka}

\author{
S Deepthi Gowda, Amruta S Bhat, Sandhyarani Nishani, V Kantharaju, \\ Abdul Kareem and HP Hadimani
}

DOI: https://doi.org/10.22271/chemi.2020.v8.i5o.10433

\begin{abstract}
Morphological and cultural variability was studied among the isolates of Fusarium spp. collected from fusarium wilt infested chilli fields of north Karnataka. The isolates cultured on potato dextrose agar medium showed considerable cultural variabilities in colony diameter, colony morphology, pigmentation and morphological variabilities in conidial size, septation and sporulation rate. Colony diameter among F. oxysporum isolates ranged from $63.93-89.87 \mathrm{~mm}$ and produced white fluffy cottony growth with orangish pigmentation. The isolates produced macro conidia of size 11.5-24 $\times 2.2-5.5 \mu \mathrm{m}$ with 3-4 septation, micro conidia of size 5-6 $\times 2.7-3 \mu \mathrm{m}$ and chlamydospore of size 10.5-11.2 $\mu \mathrm{m}$ in diameter. Colony diameter among $F$. solani isolates ranged from $57.80-89.87 \mathrm{~mm}$, and produced white-creamish cottony/fluffy/submersed growth with creamish, light orangish, purplish and pinkish pigmentation. The isolates produced macro-conidia of size 10-25.5 $\times 3-6.5$ with 2-3 septation, micro-conidia of size 5$12.5 \times 2.1-3.5 \mu \mathrm{m}$ and chlamydospores of size $10-12 \mu \mathrm{m}$ in diameter. The isolates also showed variation in sporulation rate.
\end{abstract}

Keywords: Fusarium solani, Fusarium oxysporum, chilli and variability

\section{Introduction}

Chilli (Capsicum annuum L.) belonging to family solanaceae is a globally important spice and vegetable crop. Chillies are rich source of vitamin A, vitamin C, vitamin E, folic acid, calcium, potassium and antioxidants (i.e., flavonoids, capsaicinoids and carotenoids). Different varieties are cultivated for varied uses like vegetable, pickles, spice and condiments. It is being used for imparting taste, flavour, and colour to food and also used in preservative, pharmaceutical, perfumery, cosmetic products and religious rituals etc. (Raghu et al. 2017) ${ }^{[15]}$. The major chilli growing countries are India, China, Korea, Nigeria, U.S.S.R. Mexico, etc. India is one of the largest producer and exporter of this crop with an area of 2.87 lakh ha and production of 34.06 lakh metric tonnes. India ranks second among world's chilli exporting countries. The leading chilli producing states in India are Andhra Pradesh (49\%), Maharastra (26\%), Karnataka (15\%), West Bengal (12\%), Tamil Nadu (3\%). The Karnataka follows Andhra Pradesh, which share 15 per cent of the production in the country with an area of 0.45 lakh ha and 6.07 lakh tonnes. In Karnataka the crop is mainly cultivated in districts like Dharwad, Haveri, Koppal, Bellary, Raichur, Kalburgi and Belgavi (Anon., 2017) ${ }^{[2]}$. A number of biotic and abiotic stresses are a constraint in chilli production. The main biotic factors are diseases due to fungi, bacteria and viruses, which have drastically restricted the yield potential and quality. Among these, fusarium wilt has emerged as a serious problem in recent years. The yield loss due to the disease is known to vary from 10-50 per cent worldwide and 10-80 percent in Karnataka. (Loganathan et al., 2013) ${ }^{[11]}$. In different chilli growing states of India wilt incidence varied from 2.0 to 85.0 percent in (Anon, 2005) ${ }^{[1]}$. In Karnataka major planting seasons are kharif: June-July and Rabi: October-November. Prevalence of warm temperature, high humidity with high soil moisture coinciding with active growth period of the crop favours development of fusarium wilt (Shali, 2000). Fusarium wilt symptoms are characterised by yellowing of foliage, upward and inward rolling of leaves, progressive wilting of foliage leading to a permanent wilt and death of the plant, and a reddish or brownish discolouration of the vascular tissue (MacHardy and Beckman, 1981; Rivelli, 1989) ${ }^{[12,16] .}$ 
In chilli, wilt appears both in seedling and at later stages of the crop, and leads to highest mortality at flowering and fruiting stages. Although the disease first appears in patches in a field, it can extend to the entire field with repeated monocropping and growing of susceptible varieties. Understanding the present context of fusarium wilt incidences in all high yielding varieties of chilli in major chilli growing districts of Karnataka the present study was carried out to know the Fusarium spp. responsible and variability among different isolates.

\section{Materials and Methods}

\subsection{Collection, isolation and identification of pathogen}

Fifty one isolates were collected from major chilli growing districts of Karnataka namely Bagalkot, Bellary, Belagavi, Haveri, Raichur and Tumkur for fusarium wilt incidence. The roots and basal stem portion of completely and partially wilted plants of chilli were collected from the field. The fungal culture was isolated on PDA media from collected plant sample at temperature of $27 \pm 1^{\circ} \mathrm{C}$ and by using single hyphal tip technique pure culture was obtained. Totally 51 isolates were isolated and cultured on potato dextrose agar (PDA) media and maintained at $4{ }^{\circ} \mathrm{C}$ temperature and used for further studies. The fungal isolates were identified by comparing their morpho-cultural characters like production of spores such as micro, macro and chlamydo-spores, shape, size and septation in macro-conidia and pigmentation in culture with those described by Leslie and Summerell (2006) ${ }^{[9]}$.

\subsection{Cultural variability}

All 51 isolates of Fusarium were designated as FS (Fusarium solani)/FO (Fusarium oxysporum) and characterized on the basis of their cultural and morphological characters on PDA. The type of colony, colony diameter, conidial size, septation and sporulation rate were recorded at $3^{\text {rd }}, 5^{\text {th }}$ and $7^{\text {th }}$ day after incubation.

\subsection{Morphological variability}

Fifty one isolates of Fusarium spp. collected from different regions were cultured on potato dextrose agar medium and taken for morphological studies. Culture was mounted on slide in lactophenol cotton blue mounting medium and observed under microscope fitted with camera (Symbiont Technologies DM-2020®) under high power magnification (40X). Observations on conidial characters like type of conidia, size, number of septation and sporulation rate were recorded. For counting sporulation rate, spores from 3 microscopic fields were counted and averaged. Based on the average number of spores per microscopic field the isolates were categorized under high sporulation, medium sporulation and less sporulation if conidia were $>50,30-50,<30$ respectively.

\section{Results}

\subsection{Isolation, purification and identification of pathogen}

A total of fifty one isolates of fungus were isolated from chilli plant samples collected from different places by standard tissue isolation procedure and they were purified and maintained on PDA as described in material and methods. The fungal isolates were identified by comparing their morpho-cultural characters like production of spores such as micro, macro and chlamydo-spores, shape, size and septation in macro-conidia and pigmentation in culture with those described by Leslie and Summerell (2006) ${ }^{[9]}$. Out of 51 isolates, three isolates (FO 22, FO 26, FO 30) were identified as $F$. oxysporum and 48 isolates were identified as $F$. solani. Fusarium oxysporum had thin-walled, relatively slender and 3-5 septate macro-conidia, evenly curved fusoid with the widest part in the middle and pointed at both the ends. The micro-conidia were formed on smaller false heads with floccose, sparse or abundant mycelia, which ranged from white to pale violet in pigmentation. Whereas, Fusarium solani had thick-walled, curved, dorsoventrally straight, relatively wider, stout and robust macro-conidia with the widest diameter in the upper half of the spore. The microconidia were monophilidic and formed on relatively longer false heads with white to cream colour pigmentation with sparse mycelium. The chlamydospores were formed singly, in pairs, in chains or in clumps in both the species. Chlamydospores of $F$. solani were smooth textured whereas; in $F$. oxysporum they were rough textured.

\subsection{Cultural characters of isolates on PDA}

Three $F$. oxysporum isolates FO 22, FO 26 and FO 30 produced white fluffy cottony growth. Among 48 isolates of F. solani 19 isolates (FS 3 to FS 7, FS 10, FS 14, FS 20, FS 31, FS 32, FS 39, FS 40, FS 41 to FS 46) produced white cottony growth, 15 isolates (FS 1, FS 2, FS 8, FS 17, FS 21, FS 23, FS 27, FS 28, FS 29, FS 34 to FS 47 produced white fluffy cottony growth, seven isolates (FS 11 to FS 13, FS 18, FS 19, FS 24, FS 38 produced white submersed cottony growth, seven isolates (FS 9, FS 15, FS 16, FS 25, FS 33, FS 50 and FS 51 creamy white cottony growth (Table 1).

Isolates produced creamish, light orangish, orangish, pinkish and light pinkish pigmentation. F. oxysporum isolates FO 22 produced light pinkish, isolate FO 26 produced purplish and FO 30 produced pinkish pigmentation. Among $48 \mathrm{~F}$. solani isolates 13 isolates (FS 1 to FS 4, FS 7, FS 8, FS 9, FS 15, FS 16, FS 21, FS 32, FS 47 FS 48 and FS 49) produced creamish pigmentation and rest of the isolates (FS 5, FS 6 FS 33 to FS 37, FS 39 to FS 46) produced orangish pigmentation (Table 1).

After seven days incubation, $F$. oxysporum isolates showed highest radial growth of $89.87 \mathrm{~mm}$ in isolate FO 30, 75.33 $\mathrm{mm}$ in isolate FO 26 and least mycelial growth of $63.93 \mathrm{~mm}$ in isolate FO 22 respectively. However, among the 48 isolates, 18 isolates (FS 4, FS 8, FS 17, FS 18,FS 27, FS 28, FS 33, FS 34, FS 36, FS 38 to FS 40, FS 42 to FS 44, FS 49 to FS 51) showed highest radial growth in range of 85.53- 89.93 mm, 25 isolates (FS 1 to FS 3, FS 5 to FS 7, FS 9, FS 11 to FS 13, FS 16, FS 19 to FS 21, FS 23 to FS 25, FS 31, FS 35, FS 37, FS 41, FS 45 to FS 48) showed radial growth of 73.47$79.93 \mathrm{~mm}, 5$ isolates (FS 10, FS 14, FS 15, FS 29, FS 32) showed least radial growth of 57.80- $65.67 \mathrm{~mm}$ (Table 1).

\subsection{Morphological characters of isolates on PDA}

Studies on morphological variability of 51 isolates of Fusarium on potato dextrose agar indicated that, all the isolates produced both micro and macro-conidia and chlamydopores. However, isolates varied with rate of production of spore, size of macro and microspores. In isolates of $F$. oxysporum, the mean size of macro-conidia ranged from $13.5-24.5 \times 2.25-5.5 \mu \mathrm{m}$ and the mean size of micro-conidia ranged from $5-6 \times 2.7-3 \mu \mathrm{m}$ with 3 septation. In case of $\mathrm{F}$. solani isolates, the mean size of the macro-conidia ranged from $8-29 \times 2.5-6.5 \mu \mathrm{m}$ and that of micro-conidia ranged from $5-18.5 \times 2.2-4.5 \mu \mathrm{m}$ with $2-3$ septa. The chlamydospores produced in different isolates were either 
smooth and/or rough with size range of 9.5-12.5 $\mu \mathrm{m}$ in diameter. The overall sporulation rate was high in one isolate of F. oxysporum (FO 26) and 17 isolates of $F$. solani, whereas, ten isolates were found to have medium sporulation and 21 isolates had less sporulation.

\section{Discussion}

A total of fifty one isolates of fungus were isolated from wilted chilli plant samples collected from different locations of Karnataka, purified and identified based on their morphocultural characters. By comparing the morpho-cultural characters of 51 isolates with that described by Leslie and Summerell (2006) ${ }^{[9]}$, three isolates (FO 22, FO 26 and FO 30) were identified as $F$. oxysporum and 48 isolates were identified as $F$. solani. The micro-conidia produced by the pathogens were monophilidic and these were formed on relatively long false heads in $F$. solani and on smaller false heads in $F$. oxysporum isolates. The $F$. oxysporum isolates produced thin-walled, relatively slender, indistinctly septate macro-conidia, evenly curved, fusoid with the widest part in the middle. They were thin-walled with 3-5 septa and pointed at both the ends with purple or pinkish pigmentation. Similarly, $F$. solani isolates produced thick-walled, curved, dorsoventrally straight, relatively wider, stout and robust macro-conidia, which had the widest diameter in the upper half of the conidia. Micro-conidia of $F$. solani isolates were wider, more oval in shape with thicker walls. It produced cream to orangish pigmentation. Similar descriptions were also reported by (Rozlianah and Sariah, 2006; Patil et al., 2014; Isaac et al., 2018) who differentiated and identified $F$. solani and $F$. oxysporum. The progressive and relative radial growth of the fungus recorded at $3 \mathrm{rd}$, 5th and 7 th day of incubation on PDA showed significant variations among isolates. Present findings are in agreement with many other reports. The colony of $F$. solani isolates were white cottony with aerial mycelia and produced purple, pink or orangish pigmentation and $F$. oxysporum isolates produced white cottony aerial mycelia and purple, pink or pale violet pigmentation (Devika Rani et al., 2007; Gogoi et al., 2017; Ferniah et al., 2014; Mohammed et al., 2016) ${ }^{[4,6,5,13]}$. Kadam et al. (2012) ${ }^{[8]}$ reported that potato dextrose agar supported maximum mycelial growth in different isolates of Fusarium oxysporum f.sp.ciceri. The differential colour of the $F$. oxysporum and $F$. solani isolates may be due to the presence of specific pigments (viz., javanicin, bostrycoidin, solanione and lycopersin) produced by these isolates (Booth, 1971) ${ }^{[3]}$. Lilly and Barnet (1951) ${ }^{[10]}$, reported that nutritional requirement of different fungi differs and best growth may be obtained in particular media. Variations in growth might be due to differential ability of the isolates to utilize different nutritional source. Variations in size of macro and microconidia in different Fusarium spp. and isolates has also been reported by many other workers (Nirmaladevi and Srinivas, 2012; Ferniah et al., 2014; Devika Rani et al., 2007; Hafizi et al., 2013; Gogoi et al., 2017) [14, 5, 4, 6, 7]. Nirmaladevi and Srinivas (2012) ${ }^{[14]}$ reported that size of macro-conidia was $15.0-37.5 \times 2.5-4.0 \mu \mathrm{m}$ and that of micro-conidia was 2.5$15.0 \times 2.0-3.0 \mu \mathrm{m}$ in $F$. oxysporum f.sp. lycopersici. In $F$. solani size of macro-conidia varied from 27.0-46.0 x 3.0-4.5 $\mu \mathrm{m}$ with 3-5 septations and 16.8-66.0 x 4.0-6.28 $\mu \mathrm{m}$ with $1-5$ septations; and that of microconidia varied from 5.0-15.0 $\mathrm{x}$ 2.2-3.5 $\mu \mathrm{m}$ and 5.75-15.2 x 3.8-7.4 $\mu \mathrm{m}$ (Ferniah et al., 2014; Devika Rani et al., 2007) ${ }^{[5,4]}$.

Table 1: Growth characters of Fusarium isolates on Potato dextrose agar medium after seven days of incubation

\begin{tabular}{|c|c|c|c|c|c|c|}
\hline \multirow{2}{*}{ Isolate Name } & \multirow{2}{*}{ Place of collection } & \multirow{2}{*}{ Colony characters } & \multicolumn{3}{|c|}{ Mean Colony diameter(mm) } & \multirow{2}{*}{ Pigmentation } \\
\hline & & & 3 & 5 & 7 & \\
\hline FS 1 & Kaginele & White fluffy cottony & 79.33 & 43.33 & 59.20 & Creamish \\
\hline FS 2 & Kaginele & White fluffy cottony & 77.33 & 35.33 & 55.13 & Creamish \\
\hline FS 3 & Chikningdalu & White cottony & 79.87 & 38.67 & 53.67 & Creamish \\
\hline FS 4 & Chikningdalu & White cottony & 89.53 & 48.67 & 78.67 & Creamish \\
\hline FS 5 & Dasanakoppa & White cottony & 75.87 & 39.33 & 53.67 & Orangish \\
\hline FS 6 & Dasanakoppa & White cottony & 79.87 & 44.67 & 57.87 & Orangish \\
\hline FS 7 & Haladakatti & White cottony & 79.73 & 45.33 & 63.33 & Creamish \\
\hline FS 8 & Haladakatti & White fluffy cottony & 89.47 & 47.33 & 66.67 & Creamish \\
\hline FS 9 & Madihalli & Creamy white submersed cottony & 79.60 & 45.00 & 62.67 & Creamish \\
\hline FS 10 & Madihalli & White cottony & 69.53 & 39.20 & 55.67 & Orangish \\
\hline FS 11 & Beniwad & White submersed cottony & 79.93 & 39.33 & 57.33 & Light Orangish \\
\hline FS 12 & Beniwad & White submersed cottony & 77.80 & 34.67 & 49.33 & Light Orangish \\
\hline FS 13 & Hexambada & White submersed cottony & 73.47 & 39.33 & 53.67 & Creamish \\
\hline FS 14 & Hexambada & White cottony & 65.67 & 28.67 & 42.67 & Light Orangish \\
\hline FS 15 & Karoshi & Creamy white submersed cottony & 63.87 & 37.33 & 49.53 & Creamish \\
\hline FS 16 & Karoshi & Creamy white submersed cottony & 75.60 & 45.33 & 57.07 & Creamish \\
\hline FS 17 & Shaktinagar & White fluffy cottony & 85.53 & 39.33 & 69.53 & Light Orangish \\
\hline FS 18 & Shaktinagar & White submersed cottony & 89.73 & 38.67 & 69.27 & Light Pinkish \\
\hline FS 19 & Devsoogoor & White submersed cottony & 79.20 & 38.00 & 59.87 & Light Orangish \\
\hline FS 20 & Devsoogoor & White cottony & 73.80 & 38.67 & 59.07 & Orangish \\
\hline FS 21 & Neeramanvi & White fluffy cottony & 79.60 & 39.33 & 53.73 & Creamish \\
\hline FO 22 & Neeramanvi & White cottony fluffy & 63.93 & 39.00 & 47.60 & Light Pinkish \\
\hline FS 23 & Kapgal & White cottony fluffy & 79.73 & 38.53 & 49.67 & Orangish \\
\hline FS 24 & Kapgal & White submersed cottony & 79.67 & 39.67 & 63.47 & Orangish \\
\hline FS 25 & Hospet & Creamy white cottony & 79.27 & 38.47 & 59.20 & Orangish \\
\hline FO 26 & Hospet & White fluffy cottony & 75.33 & 36.87 & 57.80 & Purplish \\
\hline FS 27 & Kamalapura & White fluffy cottony & 87.60 & 38.80 & 63.93 & Pinkish \\
\hline FS 28 & Kamalapura & White fluffy cottony & 89.73 & 49.67 & 71.53 & Pinkish \\
\hline FS 29 & Lakshmipura & White fluffy cottony & 57.80 & 24.80 & 33.53 & Purplish \\
\hline FO 30 & Lakshmipura & White fluffy cottony & 89.87 & 46.67 & 69.47 & Pinkish \\
\hline
\end{tabular}




\begin{tabular}{|c|c|c|c|c|c|c|}
\hline FS 31 & Kampli & White cottony & 77.87 & 41.33 & 59.13 & Light Orangish \\
\hline FS 32 & Kampli & White cottony & 67.67 & 35.80 & 47.47 & Creamish \\
\hline FS 33 & Hasundi & Creamy white submersed cottony & 87.87 & 38.60 & 61.33 & Orangish \\
\hline FS 34 & Hasundi & White fluffy cottony & 89.87 & 41.27 & 67.33 & Orangish \\
\hline FS 35 & Halageri & White fluffy cottony & 79.53 & 39.07 & 59.27 & Orangish \\
\hline FS 36 & Halageri & White fluffy cottony & 89.73 & 46.67 & 65.27 & Orangish \\
\hline FS 37 & Kakola & White cottony growth & 77.80 & 45.67 & 63.93 & Orangish \\
\hline FS 38 & Kakola & White cottony submersed & 89.93 & 42.67 & 63.80 & Pinkish \\
\hline FS 39 & Alagur & White cottony & 89.87 & 49.67 & 79.33 & Orangish \\
\hline FS 40 & Alagur & White cottony & 89.33 & 49.00 & 78.67 & Orangish \\
\hline FS 41 & Guledagudda & White cottony & 77.80 & 45.67 & 63.53 & Orangish \\
\hline FS 42 & Guledagudda & White cottony & 89.53 & 47.53 & 67.53 & Orangish \\
\hline FS 43 & Kaladgi & White cottony & 89.87 & 49.67 & 79.20 & Orangish \\
\hline FS 44 & Kaladgi & White cottony & 89.73 & 47.87 & 66.93 & Orangish \\
\hline FS 45 & Siddapura & White cottony & 77.93 & 45.93 & 63.93 & Orangish \\
\hline FS 46 & Siddapura & White cottony & 77.73 & 45.67 & 61.87 & Orangish \\
\hline FS 47 & Rampura & White fluffy cottony & 79.73 & 38.67 & 57.80 & Creamish \\
\hline FS 48 & Jangere White cottony & 79.80 & 37.20 & 57.93 & Creamish \\
\hline FS 49 & Kolaramanahalli & White cottony & 89.87 & 39.27 & 49.53 & Creamish \\
\hline FS 50 & Kotaldinnae & Creamy white fluffy cottony & 85.87 & 49.53 & 60.93 & Light Orangish \\
\hline FS 51 & Ramestripalya & Creamy white fluffy cottony & 87.87 & 39.13 & 59.93 & Orangish \\
\hline \multicolumn{2}{|r|}{ CD $(0.01)$} & 41.45 & 60.36 & 80.64 \\
\hline S.Em $\pm \quad 0.013$ & 0.105 & 0.051 \\
\hline
\end{tabular}

Table 2: Morphological variability of Fusarium isolates of chilli collected from different locations of Karnataka

\begin{tabular}{|c|c|c|c|c|c|c|c|c|c|c|}
\hline \multirow{2}{*}{$\begin{array}{l}\text { Isolate } \\
\text { name }\end{array}$} & \multirow{2}{*}{$\begin{array}{c}\text { Overall } \\
\text { sporulation } \\
\text { rate }\end{array}$} & \multicolumn{4}{|c|}{ Macrospores } & \multicolumn{3}{|c|}{ Microspores } & \multirow{2}{*}{\begin{tabular}{|c|} 
Chlamydospore \\
$\begin{array}{c}\text { Diameter } \\
(\mu \mathrm{m})\end{array}$ \\
\end{tabular}} & \multirow[b]{2}{*}{$\begin{array}{c}\text { Chlamydospore } \\
\text { rate }\end{array}$} \\
\hline & & $\begin{array}{c}\text { Length } \\
(\mu \mathrm{m})\end{array}$ & $\begin{array}{c}\text { Width } \\
(\mu \mathrm{m})\end{array}$ & Septation & $\begin{array}{c}\text { Macrospore } \\
\text { rate }\end{array}$ & $\begin{array}{c}\text { Length } \\
(\mu \mathrm{m})\end{array}$ & $\begin{array}{c}\text { Width } \\
(\mu \mathrm{m})\end{array}$ & $\begin{array}{c}\text { Microspore } \\
\text { rate }\end{array}$ & & \\
\hline FS 1 & + & 17 & 4.1 & $2-3$ & + & 12.5 & 3.5 & + & 10.5 & + \\
\hline FS 2 & ++ & 16 & 4.3 & $2-3$ & + & 9.5 & 3.1 & + & 11.35 & + \\
\hline FS 3 & +++ & 15 & 3.9 & $2-3$ & ++ & 8 & 3.2 & +++ & 10.5 & ++ \\
\hline FS 4 & +++ & 13 & 4.1 & 2 & ++ & 7.5 & 3.1 & +++ & 12 & ++ \\
\hline FS 5 & +++ & 23.5 & 6.1 & $2-3$ & + & 10.5 & 2.9 & ++ & 10 & ++ \\
\hline FS 6 & +++ & 15.5 & 4.1 & $2-3$ & + & 7 & 2.2 & + & 12 & ++ \\
\hline FS 7 & ++ & 15.5 & 5 & 2 & + & 8 & 2.9 & ++ & 10.5 & ++ \\
\hline FS 8 & +++ & 14 & 4 & 2 & + & 9.5 & 3.5 & +++ & 9.5 & + \\
\hline FS 9 & + & 12 & 3.5 & $2-3$ & + & 8.2 & 3.2 & + & 12 & +++ \\
\hline FS 10 & + & 11 & 3 & $2-3$ & + & 7.3 & 3 & + & 10 & +++ \\
\hline FS 11 & ++ & 13.5 & 4 & $2-3$ & + & 7 & 3.2 & + & 11 & +++ \\
\hline FS 12 & ++ & 12 & 3.5 & $2-3$ & + & 8 & 3.1 & + & 10.25 & +++ \\
\hline FS 13 & +++ & 18 & 4.5 & $2-3$ & + & 7 & 3.1 & +++ & 11.5 & ++ \\
\hline FS 14 & +++ & 17 & 3.2 & $2-3$ & ++ & 9.5 & 3.2 & +++ & 12.5 & ++ \\
\hline FS 15 & +++ & 11.5 & 3.2 & 2 & + & 8 & 3 & +++ & 12.25 & ++ \\
\hline FS 16 & ++ & 11 & 3.2 & 2 & + & 9 & 3.2 & + & 11.5 & +++ \\
\hline FS 17 & + & 12 & 3 & 2 & + & 7.5 & 3.1 & + & 10.85 & +++ \\
\hline FS 18 & + & 12.5 & 3 & $2-3$ & + & 6.5 & 2.1 & + & 11.2 & +++ \\
\hline FS 19 & ++ & 11.5 & 2.5 & $2-3$ & + & 9.3 & 3.3 & ++ & 11 & ++ \\
\hline FS 20 & + & 25.5 & 6 & $2-3$ & + & 8 & 2.2 & + & 9.5 & +++ \\
\hline FS 21 & +++ & 12.5 & 3.5 & $2-3$ & + & 6 & 2.9 & +++ & 11.25 & + \\
\hline FO 22 & + & 13.5 & 2.2 & 3 & + & 5 & 2.7 & + & 10.5 & + \\
\hline FS 23 & +++ & 12 & 3.2 & 2 & + & 11 & 3 & +++ & 11.5 & +++ \\
\hline FS24 & + & 13 & 3.2 & $2-3$ & + & 10.5 & 3.2 & + & 11 & +++ \\
\hline FS25 & +++ & 14 & 4.5 & 3 & ++ & 9.5 & 2.8 & +++ & 12 & +++ \\
\hline FO26 & +++ & 24 & 5.5 & $3-4$ & ++ & 6 & 3 & +++ & 11.2 & + \\
\hline FS27 & + & 13 & 3.4 & $2-3$ & + & 7 & 3.2 & + & 10.8 & +++ \\
\hline FS28 & + & 12 & 3 & 2 & + & 6 & 2.9 & + & 9.5 & +++ \\
\hline FS29 & + & 13 & 3 & $2-3$ & + & 5 & 2.5 & + & 12 & +++ \\
\hline FO30 & + & 11.5 & 3 & 3 & + & 6 & 2.9 & + & 11.2 & +++ \\
\hline FS31 & + & 14 & 3.5 & $2-3$ & ++ & 7 & 2.8 & ++ & 10.5 & +++ \\
\hline FS32 & + & 13 & 4 & 2 & ++ & 12 & 2.9 & ++ & 11.2 & +++ \\
\hline FS33 & +++ & 13 & 3.2 & 2 & ++ & 8 & 3.1 & + & 11.8 & +++ \\
\hline FS34 & + & 11 & 3 & 2 & + & 7.5 & 2.5 & + & 12 & +++ \\
\hline FS35 & +++ & 16 & 4.5 & $2-3$ & ++ & 8.5 & 3.1 & ++ & 10.5 & +++ \\
\hline FS36 & +++ & 17.5 & 4 & $2-3$ & ++ & 7 & 3 & ++ & 11.5 & +++ \\
\hline FS37 & +++ & 11.5 & 3.5 & 2 & + & 9.5 & 3.3 & +++ & 12.2 & +++ \\
\hline FS38 & ++ & 18.5 & 4.5 & 2 & + & 8.5 & 3.2 & + & 11.5 & + \\
\hline FS39 & + & 10 & 3 & 2 & + & 8.5 & 2.5 & + & 10.5 & +++ \\
\hline
\end{tabular}




\begin{tabular}{|l|c|c|c|c|c|c|c|c|c|c|}
\hline FS40 & + & 11.5 & 3 & 2 & + & 6 & 2.2 & + & 10 & +++ \\
\hline FS41 & + & 14 & 4 & $2-3$ & + & 4 & 2.9 & + & 11.2 & +++ \\
\hline FS42 & + & 13 & 3.5 & 2 & + & 8 & 3.5 & + & 10.5 & +++ \\
\hline FS43 & + & 10 & 3.5 & $2-3$ & + & 7 & 2.8 & + & 11.5 & ++ \\
\hline FS44 & + & 12 & 2.5 & 2 & + & 6 & 3.2 & + & 12 & +++ \\
\hline FS45 & ++ & 10.5 & 3 & 2 & + & 7.2 & 3 & ++ & 10.5 & ++ \\
\hline FS46 & + & 11 & 3 & 2 & + & 5.8 & 2.5 & + & 10.25 & ++ \\
\hline FS47 & +++ & 13.5 & 3.5 & $2-3$ & + & 9.2 & 3 & +++ & 12 & + \\
\hline FS48 & ++ & 17.5 & 4.5 & $2-3$ & + & 7.5 & 3 & + & 9.5 & + \\
\hline FS49 & ++ & 15 & 4.5 & 2 & ++ & 7.5 & 3 & + & 11.5 & + \\
\hline FS50 & +++ & 16 & 4.9 & 2 & ++ & 8 & 2.9 & +++ & 10.2 & + \\
\hline FS51 & +++ & 15 & 4.8 & 2 & + & 11.5 & 3.3 & +++ & 11.25 & + \\
\hline
\end{tabular}

$+++=$ High sporulation $(>50$ spores per microscopic field $)++=$ Medium sporulation $(30-50$ spores per microscopic field $)+=$ Less sporulation (30 spores per microscopic field)

\section{Conclusion}

In the respective study, we isolated and identified 51 isolates of Fusarium. Among them three isolates (FO 22, FO 26, FO 30) were identified as F.oxysporum and rest of the isolates was identified as $F$. solani. The isolates showed lot of cultural and morphological variabilities on PDA media and thus variation among the isolates was existed and confirmed.

\section{Acknowledgement}

The authors thank Department of Plant Pathology, Kittur Rani Channamma College of Horticulture, Arabhavi, University of Horticultural Sciences, Bagalkot, Karnataka, India for providing all possible facilities for present study in partial fulfilment of M. Sc research work.

\section{Reference}

1. Anonymous. Annual report of network project on wilt of chilli with special reference to cultural, morphological, molecular characterization and pathogenic variability of isolates of India. submitted to ICAR, New Delhi, 2005, 7.

2. Anonymous. 2017; National Horticulture Board, http;//www.nhb.gov.in.

3. Booth C. The Genus Fusarium. Commonwealth Mycological Institute, Kew Surrey, England, 1971, 237.

4. Devika Rani GS, Naik MK, Raju K, Prasad PS. Prevalence of Wilt of Chilli and assessment of population dynamics of Fusarium in predominant Chilli (Capsicum annuит L.) growing regions of Karnataka. Soil Biol. 2007; 27(1\&2):50-61.

5. Ferniah RS, Daryono BS, Kasiamdari RS, Priyatmojo A. Characterization and pathogenicity of Fusarium oxysporum as the causal agent of fusarium wilt in chilli (Capsicum annuum L.). J Microbiol., 2014; 8(3):121-126.

6. Gogoi M, Sarmah DK, Ali S. Cultural and morphological variations of Fusarium solani (Mart.) Sacc. causing root rot of patchouli in Assam, India. Int. J Curr. Microbiol. App. Sci. 2017; 6(11):1889-1901.

7. Hafizi R, Salleh B, Latiffah Brazilian Z. Morphological and molecular characterization of Fusarium solani and $F$. oxysporum associated with crown disease of oil palm. J Microbiol. 2013; 44(3):959-968.

8. Kadam N, Mane SS, Katkar M. Pathogenicity, nutrition and host differential reaction of isolates of Fusarium oxysporum f.sp. ciceri causing chickpea wilt from Maharashtra. J Plant Dis. Sci. 2012; 7(2):185-189.

9. Leslie JF, Summerell BA. The Fusarium Laboratory Manual. Blackwell Publishing Ltd., Victoria, Australia, 2006, 388.

10. Lilly VG, Barnett HL. Physiology of Fungi. Mc-Graw Hill Book Co. Inc., London, U.K., 1951, 30-80.
11. Loganathan M, Venkataravanappa V, Saha S, Sharma BK, Tirupathi S, Verma MK. Morphological, cultural and molecular characterizations of Fusarium wilt infecting tomato and chilli. In: National Symposium on Abiotic and Biotic Stress Management in Vegetable Crops, Indian Society of Vegetable Science, IIVR. Varanasi, 2013.

12. MacHardy WE, Beckman CH. Vascular wilt Fusaria: Infections and Pathogenesis. In: Fusarium: Diseases, Biology and Taxonomy, (Eds.) Nelson, P.E., Toussoun, T.A. and Cook, R.J. The Pennysylvania State University Press, University Park and London, 1981, 365-390.

13. Mohammed AS, Kadar NH, Kihal M, Henni JE, Sanchez J, Gallego E, Cardenas JAG. Characterization of Fusarium oxysporum isolates from tomato plants in Algeria. African J of Microbiol. Res. 2016; 10(30):11561163.

14. Nirmaladevi D, Srinivas C. Cultural, Morphological, and Pathogenicity Variation in Fusarium oxysporum f. sp. lycopersici Causing Wilt of Tomato. Sci. Rep. 2012; 6:21367-213680.

15. Raghu S, Benagi VI, Nargund VB. Cultural, morphological and pathogenic variability among the isolates of Fusarium solani causing wilt disease of chilli. Int. J. of Agri. Sci. and Res. 2017; 4:6 96-105.

16. Rivelli VA. wilt of pepper incited by Fusarium oxysporum f.sp. capsici forma specialis nova. M.Sc. Thesis, Louisiana State University, Baton Ronge, 1989, 72.

17. Singh JK, Kumar M, Kumar A. Mehta N. Screening of chilli cultivars against fusarium wilt of chilli (Capsicum annuum). Int. J Agri. Sci. Res. 2017; 7(1):235-240. 